\title{
アルミニゥムのサブクロライド反応におよほす 鉄,ケイ素,ニッケル,銅などの影響*
}

菊池武昭**

Takeaki Kikuchi : Effects of Iron, Silicon, Nickel and Copper on the Reaction of Aluminum Subchloride Process (Study of Extractive Metallurgy of Aluminum(III)) .

The effects of iron, silicon, nickel and copper on the reaction of aluminum subchloride process were investigated by the flow method of aluminum trichloride at reduced pressure and in the temperature range of $900^{\circ} \sim 1100^{\circ} \mathrm{C}$.

In all cases, the extraction rate of aluminum decreased with the increase in the contents of alloying elements, and increased with increasing temperature and supplying rate of aluminum trichloride. The extraction rate of aluminum could be expressed by the following equation including activity of aluminum and partial pressure of aluminum trichloride.

$$
V=1.28 a_{\mathrm{Al}}^{2} \cdot P_{\mathrm{AlCl} 3}^{4 / 3} \cdot e^{-11800 / R T} \quad\left(\mathrm{Al} \mathrm{g} / \mathrm{cm}^{2} \cdot \mathrm{min}\right)
$$

The contents of silicon and iron in the deposited aluminum were about $0.2 \%$ and $0.05 \%$ respectively, and little amounts of copper and nickel transferred to the products. In addition, the experimental results were discussed using the thermodynamic calculation.

(Received February 12, 1971)

** 金属材料技術研究所，現在：新居浜工業高等専門学 校(National Research Institute for Metals, Tokyo. Present address : Department of Metallurgical Engineering, Niihama Technical College, Niihama)

* 1967 年 10 月本会札幌大会に発表；アルミニウム製 錬に関する研究(第3 報)

\section{I. 腥 言}

アルミニウムのサブクロライド製鍊においてはこれま でに平衡論的研究は数多く発表されている.

しかしながら，粗合金中に含まれる他種金属のアルミニ 
ウムの抽出速度に拉よぼす影響, また抽出アルミニウムへ の混入量などの問題は最も重要な点であるにもかかわら ずこれに関する論文は合成した合金についての田辺 ${ }^{(1)}$ らびに三谷(2)らの研究，また粘土の炭素還元で得られた合

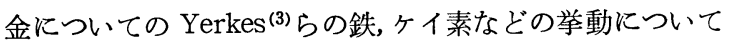
の報告が主なものであって，その数は比較的少ない。

そこで本実験は，先に発表したサブクロライド反応の平 衡(4)ならびに反応速度 ${ }^{(5)}$ にひつづいて, 反応速度に拈よ ぼす鉄, ケイ素, ニッケル，銅などの影響を検討した。

この製鍊法に扔いて関係する他種金属には，粗合金製造 の際に原料からはいる鉄, ケイ素などが主なるのである

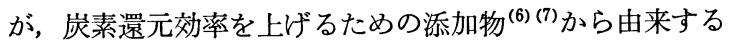
銅, ニッケルなどあとりあげ, 抽出速度に扣よぼす温度や 合金濃度の影響, 三塩化アルミニウムの流速との関係, 抽 出アルミニウムの純度などを調べた。

\section{II. 実験装置ならびに実験方法}

\section{1. 実験装置}

本実験で用いた装置は，純アルミニウムと三塩化アルミ ニウムの反応速度を求めた場合 ${ }^{(5)}$ と全く同様なもので, 三 塩化アルミニウムガス蒸発部, 反応管, 三塩化アルミニウ ム凝縮部，真空ポンプなどからなっている.

反応管には不透明石英管 (内径 $40 \mathrm{~mm}$, 長さ $800 \mathrm{~mm}$ ) を 析出用内捙管にはアルミナ管 (内径 $35 \mathrm{~mm}$, 長さ $600 \mathrm{~mm}$ ) を使用した，反応管の加熱には上下に開閉できるテュラン

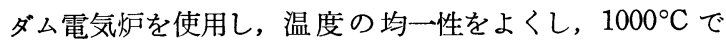
の温度偏差を炉長 $12 \mathrm{~cm}$ にわたって $\pm 5^{\circ} \mathrm{C}$ 以下にした。

温度測定には補正した Pt-Pt.Rh 熱電対を使用し, 試料 を入れたボートの直上の反応管外壁面で測定したが，内外 の温度差は認められなかった。

末反応招よび不均化反応に上り生成された三塩化アルミ ニウムガスは, 他方の出口より排出させ，これを液体窒素 で泠却して凝縮させた。

アルミニウム合金の作製には，Al-Si， Al-Fe，Al-Cu， A1-Ni 合金のそれぞれの組成に応じて，アルミニウムは 99.99\%のインゴットを適当に切断し，ケイ素はトリクロ ルシランを水素還元して得た高純度のるの, 鉄は電解鉄 $(99.9 \% \mathrm{Fe})$, ニッヶルは $99.9 \%$ のモンドニッケル、銅は 電解銅を用い, 高周波真空溶解炉で溶製した。

合金組成は $\mathrm{Al}-\mathrm{Si}$ 系 $(9.98 \% \mathrm{Si}, 5.01 \% \mathrm{Si}), \mathrm{Al}-\mathrm{Fe}$ 系 $(10.0 \% \mathrm{Fe}, 2.97 \% \mathrm{Fe}), \mathrm{Al}-\mathrm{Ni}$ 系 $(19.98 \% \mathrm{Ni}, 9.97 \% \mathrm{Ni})$, $\mathrm{Al}-\mathrm{Cu}$ 系 $(20.03 \% \mathrm{Cu}, 9.91 \% \mathrm{Cu})$ である. また三塩化アル

（1）田辺, 今野, 沢田, 高橋: 電気化学, 32 (1964), 285.

(2) 三谷, 永井: 金属学会誌, 34 (1970), 752 .

(3) L.A.Yerkes et al. : U.S. Bureau of Mines, Rep. Inv., 5773 (1961).

（4）菊池，黒沢，柳橋：金属学会誌，28(1964)，9.

（5）菊池，黑沢，柳橋 : 金属学会誌, $33(1969), 305$.

(6) A.Schneider and O.Hilmer : Metall, 3(1960), 186.

（7）菊池，黑沢，柳橋：金属学会誌，34(1970)，643。
ミニウムは市販特級のものを昇華精製して使用した。

\section{2. 実験方法}

三塩化アルミニウムを蒸発容器に手早く入れて科量し, そのままボールジョイントで反応管に接続した。

アルミニウム合金を入れるボートは高アルミナ製 $\left(\mathrm{Al}_{2} \mathrm{O}_{3}\right.$ 98.8 99.2\%, $\left.\mathrm{SiO}_{2} 0.3 \sim 0.4 \%\right)$ のものを使用した. ボー トはその底部を内挿管に合わせて半円状にし，高さの $2 / 3$ は 反応によってアルミニウムが減少しても, その表面積が変 わらないように直方形とした。

実験では，まずアルミニウム合金を入れたボートを反応 管内の温度均一部に装入する.つぎに蒸発容器と反応管を 接続し, 全体を真空ポンプで $10^{-3} \mathrm{~mm} \mathrm{Hg}$ の真空に引き, 炉の加熱を行なう。炉が所定温度に達したのち, あらかじ め一定温度に加熱してある蒸発炉を三塩化アルミニウム蒸 発容器に入れ, 一定温度に保持した。

三塩化アルミニウムガスの压力は蒸発容器と反応管との 間に設けたシリコンオイルマノメーター(信越化学製 $\mathrm{KF}$ 54 , 比重 1.07 オイル使用) で 5 分毎に測定したが, 圧力と 供給速度の関係については前報 ${ }^{(5)}$ に示した。

サブクロライド反応により生成したアルミニウムは，ア ルミナ管の析出部に高温側では多数の小球状, また低温側 では樹枝状結晶となって凝縮し，一方，三塩化アルミニウ ムは凝縮器で完全にトラップされる.

反応後, 蒸発器と反応管を急冷し,つづいてボート内の 合金の減少量拈よび三塩化アルミニウムの蒸発量を科量 し, これよりアルミニウムの反応率, 三塩化アルミニウム の反応率などを求めた. また析出アルミニウム中の $\mathrm{Si}, \mathrm{Fe}$, $\mathrm{Ni}, \mathrm{Cu}$ などを分析し，その混入量を求めた。実験温度は $900^{\circ}, 1000^{\circ}, 1100^{\circ} \mathrm{C}$ の各温度で行なった。な括ボート装 入試料は約 $40 \mathrm{~g}$ である. また実験後の試料断面について, マイクロアナライザーで添加金属の濃度分布をしらべたと ころ, 表面層と内部との差は認められなかった。

\section{III. 実験結果および考察}

以上のようにして得られた Al-Si, Al-Fe, Al-Cu, Al-Ni の各系合金についての実験結果をそれぞれ Fig.1，2，3，4 に示す。横軸に三塩化アルミニウムの供給速度 $(\mathrm{g} / \mathrm{min})$ な らびに圧力 $(\mathrm{mmHg})$ をとり, 縦軸に合金中のアルミニウム の抽出速度 $\left(\mathrm{g} / \mathrm{cm}^{2} \cdot \mathrm{min}\right)$ をとっている.

これらの四にみるように，各合金に拈いて，三塩化アル ミニウムの供給速度が大きくなるに従って，また反応温度 が高くなるにしたがってアルミニウムの抽出速度が增加し ている．また合金中の添加元素の濃度が増すほど，アルミ ニウムの抽出速度は減少している.

つぎにこれらの図から、アルミニウムの抽出速度におよ ぼす合金元素の種類と濃度による差異をみるため, 三塩化 アルミニウムの供給速度の $0.2,0.4,0.6 \mathrm{~g} / \mathrm{min}$ の条件を 選び，横軸に $\mathrm{Si}, \mathrm{Fe}, \mathrm{Cu}, \mathrm{Ni}$ のモル濃度, 縱軸にアルミニ 


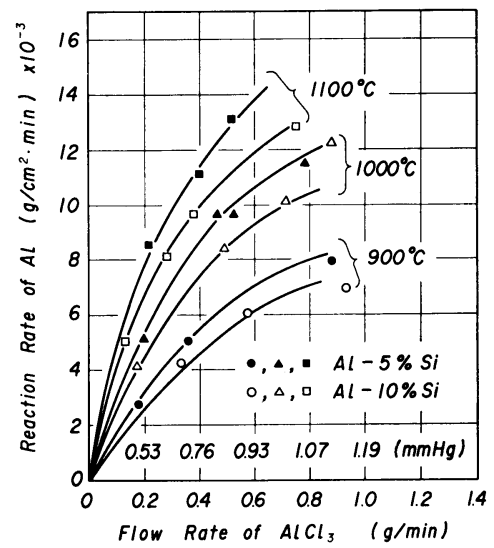

Fig.1 Relation between flow rate of $\mathrm{AlCl}_{3}$ and reaction rate of $\mathrm{Al}$ in $\mathrm{Al}-\mathrm{Si}$ alloys

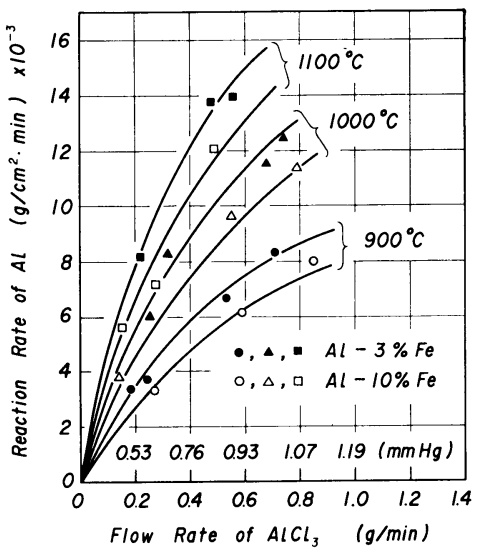

Fig.2 Relation between flow rate of $\mathrm{AlCl}_{3}$ and reaction rate of $\mathrm{Al}$ in $\mathrm{Al}-\mathrm{Fe}$ alloys

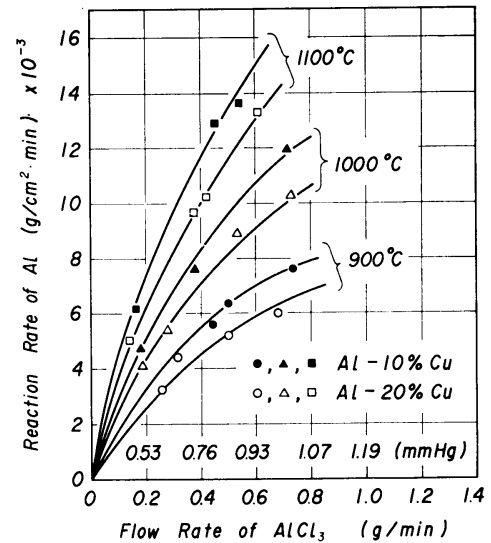

Fig.3 Relation between flow rate of $\mathrm{AlCl}_{3}$ and reaction rate of $\mathrm{Al}$ in $\mathrm{Al}-\mathrm{Cu}$ alloys

ウムの抽出速度をとって図示したのが Fig.5, 6, 7 である. この図に括いて, 前報 ${ }^{(5)}$ の純アルミニウムの抽出速度から 計算した値を, 添加物の濃度ゼロの点にとったところ, 各 合金において濃度ゼロへ外插した点とほとんど一致した。

これらの図からわかるように, 添加金属のうち同一モル \%の合金濃度では, $\mathrm{Fe}$ が最も抽出速度を遅らせている。

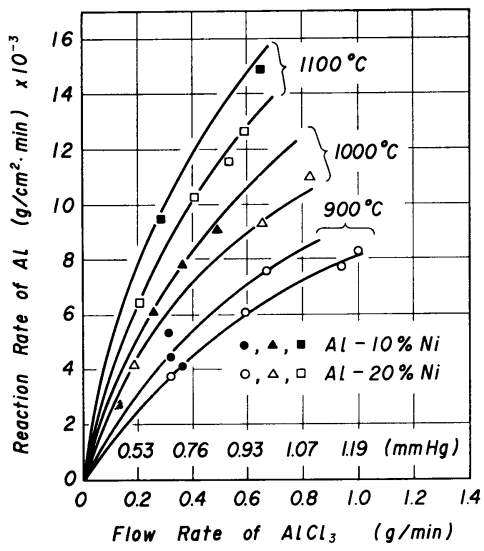

Fig.4 Relation between flow rate of $\mathrm{AlCl}_{3}$ and reaction rate of $\mathrm{Al}$ in $\mathrm{Al}-\mathrm{Ni}$ alloys

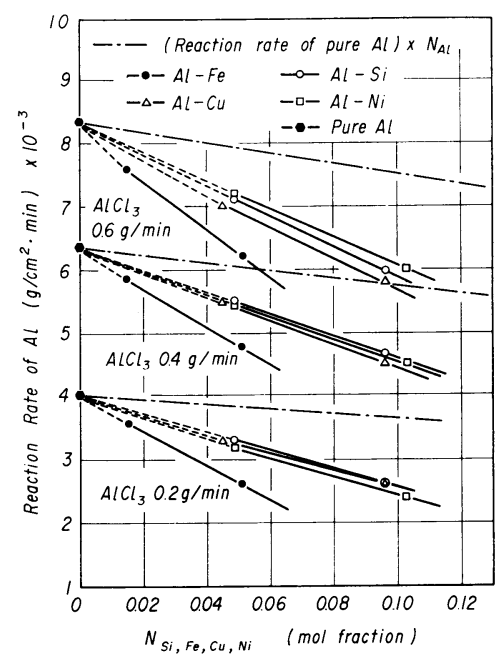

Fig. 5 Comparison of reaction rate in the $\mathrm{Al}-\mathrm{Si}, \mathrm{Al}-\mathrm{Fe}, \mathrm{Al}-\mathrm{Cu}$ and $\mathrm{Al}-\mathrm{Ni}$ alloy systems (at $900^{\circ} \mathrm{C}$ )

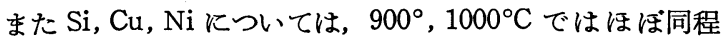
度の値を示しているが, $1100^{\circ} \mathrm{C}$ になると值が異なってく る傾向が認められた，ただし何れの合金系の場合でも，純 アルミニウムの抽出速度に合金のモル濃度を乗じた值を示 した鎖線よりも低い位置にあることがわかる.

以上の実験結果から，アルミニウムに他の金属を加えた 場合の反応速度について検討してみる，純アルミニウムの 関与するサブクロライド反応, $2 \mathrm{Al}(1)+\mathrm{AlCl}_{3}(\mathrm{~g})=3 \mathrm{AlCl}$ (g)の速度式は前報 ${ }^{(5)}$ により次式で示される.

$$
\begin{aligned}
v & =A[\mathrm{Al}]^{m}\left[\mathrm{AlCl}_{3}\right]^{n} e^{-E_{0} / R T} \\
& =1.28 P_{\mathrm{AlCl}_{3}}^{4 / 3} e^{-11800 / R T} \quad\left(\mathrm{Al} \mathrm{g} / \mathrm{cm}^{2} \cdot \mathrm{min}\right)
\end{aligned}
$$

ここで $A$ は頻度因子, $m$ と $n$ は各成分の反応次数, $[\mathrm{Al}],\left[\mathrm{AlCl}_{3}\right]$ はそれぞれの成分の濃度または分圧である.

上述の速度式は純アルミニウムに対する場合であって， 常に表面のアルミニウム濃度は一定であり，また三塩化ア ルミニウムガズの圧力, すなわち濃度の小さい場合であっ て，表面化学反応律速の条件に拉けるあのである. 


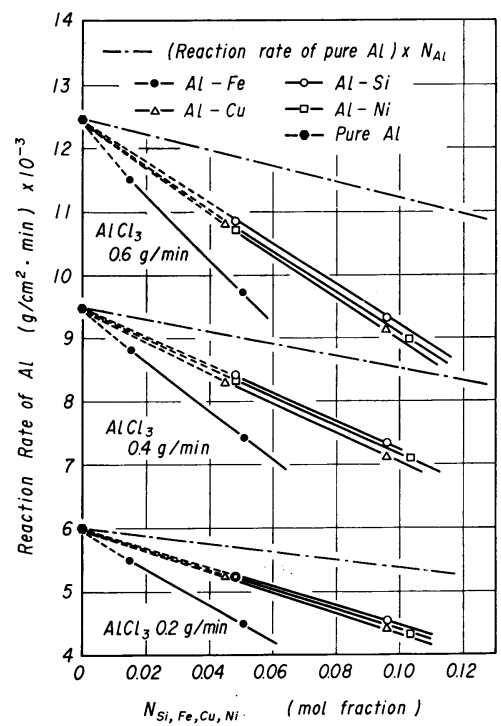

Fig. 6 Comparison of reaction rate in the $\mathrm{Al}-\mathrm{Si}, \mathrm{Al}-\mathrm{Fe}, \mathrm{Al}-\mathrm{Cu}$ and $\mathrm{Al}-\mathrm{Ni}$ alloy systems (at $1000^{\circ} \mathrm{C}$ )

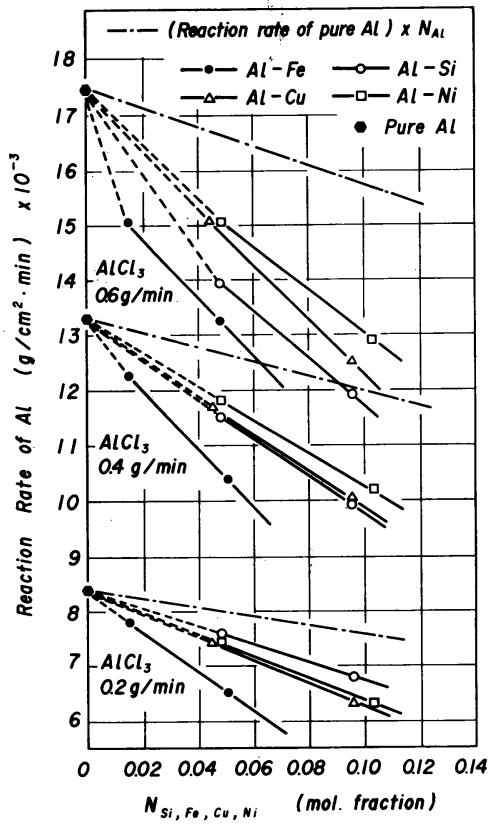

Fig.7 Comparison of reaction rate in the $\mathrm{Al}-\mathrm{Si}, \mathrm{Al}-\mathrm{Fe}, \mathrm{Al}-\mathrm{Cu}$ and $\mathrm{Al}-\mathrm{Ni}$ alloy systems (at $1100^{\circ} \mathrm{C}$ )

合金系に沏ける場合は, $2 \mathrm{Al}$ (in liq.alloy) $+\mathrm{AlCl}_{3}$ (g)= $3 \mathrm{AlCl}(\mathrm{g})$ の反応がアルミニウム合金浴とガス界面で進行 するので，その反応過程は，(1) 三塩化アルミニウムガス が，アルミニウム合金浴表面に到達する，(2) 合金浴とガ スの界面で化学反応が抗こる，(3) 浴中のアルミニウム が，ガスと合金浴界面に移動する，(4) 生成した $\mathrm{AlCl}$ ガ スが合金浴表面から離脱する，などの諸過程を含む.

これらの過程の中で(1)と(4)は，前報 (5)の純アルミニウ
ムの場合と同じく減压下で，しかもガスの流れている条件 であるため極めてすみやかであって，律速段階ではないと 考光られる.したがって本合金系で問題になるのは (2)ま たは(3)の過程である.

一般に律速段階をきめる有効な手段として，反応速度の 活性化エネルギーから評価する場合がある，本実験の各合 金系に捻いて，試みにアレニウス型の式についてそれを求 めたところ，それぞれ $\mathrm{Al}-\mathrm{Si}$ 系( $\approx 10 \%)$ で 12.9, Al-Fe 系

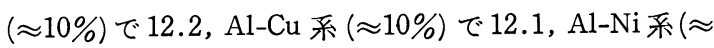
$20 \%)$ では $11.9 \mathrm{kcal} / \mathrm{mol}$ となって, 純アルミニウムの場 合の $11.8 \mathrm{kcal} / \mathrm{mol}$ とほとんど同じであり，拡散律速など でみられる数 $\mathrm{kcal} / \mathrm{mol}$ ではなかった。 そこで本研究の各 合金系です反応は表面化学反応律速と考兄られ，また添加 元素の濃度の比較的低いことも考慮すると, この場合も活 性化エネルギーに純アルミニウムについて得た值を用い て，速度式はつぎのようになる。

$$
v=1.28[\mathrm{Al}]^{m} P_{\mathrm{AlCl} 3}^{4 / 3} e^{-11800 / R T}\left(\mathrm{Al} \mathrm{g} / \mathrm{cm}^{2} \cdot \mathrm{min}\right)
$$

すなわち合金浴中のアルミニウムが，ガス－合金浴界面 へ移動する過程 (前記 (3)の条件) は律速過程とはなってお らず，アルミニウムと添加金属の相互拡散や浴の対流など により，物質移動がすみやか行なわれていることがわか る.これは，表面から底面にかけての実験後の試料を， 、 イクロアナライザーで調べたところ濃度差を認められなか ったことと一致する。

つぎに速度式の中で問題になるのは $[\mathrm{Al}]^{m}$ の項である が，この中で $m$ は，アルミニウムと三塩化アルミニウム の反応機構はどの合金系に拈いても同じと考兄られるの で，各合金系で共通の值である。 また Fig.5，6，7 でわか るように，モル濃度と反応速度の関係を示寸線からは，各 合金系にあてはまる適切な説明をつけることは困難であっ た.

以上のことからモル濃度ではなく, Peters ら ${ }^{(8)}$ が Fe-S 系溶液からの $\mathrm{H}_{2}-\mathrm{Ar}$ 混合ガスによる脱硫速度に扔いて, 硫黄の活量で速度を表わしていることを参考にし，合金中 のアルミニウムの活量を考虑してみた，すなわち各合金元 素の濃度の代りにアルミニウムの活量を横軸にとり，反応 速度を縦軸にとったのが Fig.8 と Fig.9 である.この図 の中で, $m=2$ と示した点線は, 純アルミニウムでの反応 速度にアルミニウムの活量(横軸に示した $a_{\mathrm{Al}}$ の值)の 2 乗 をかけて得られた反応速度を示す線である。

アルミニゥムの活量としては, $\mathrm{Al}-\mathrm{Si}$ 系では幸塚, 森 山(9)の值， $\mathrm{Al}-\mathrm{Cu}$ 系では松島，小野(10)， $\mathrm{Al}-\mathrm{Fe}$ 系では Coskin, Elliott(11) 拈よび三谷, 永井(12)，A1- $\mathrm{Ni}$ 系では

(8) R. J. W. Peters et al. : Trans. Faraday Soc., 61 (1965) , 1745.

（9）幸塚，八杉，中島，森山：電気化学，34(1966)，35.

(10) 大山, 松島, 小野: 東北大学選鉱製鍊研究所異報, 21 (1965) , 23.

(11) A.Coskin and J.F.Elliott : Trans.Met.Soc.AIME, 242 (1968), 253. 


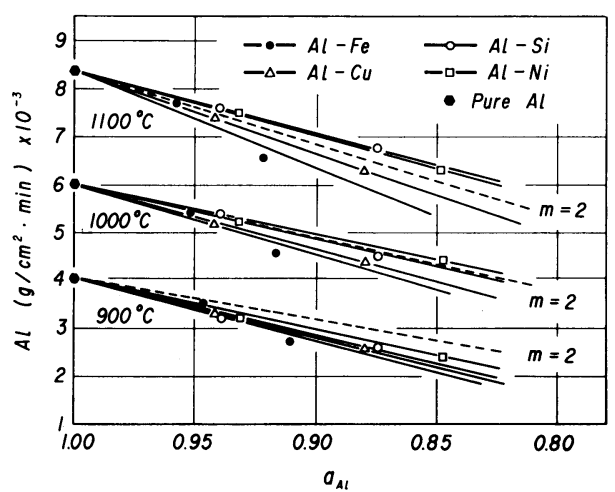

Fig. 8 Relation between reaction velocity of $\mathrm{Al}$ in the alloys and aluminum activity (Flow rate of $\mathrm{AlCl}_{3}, 0.2 \mathrm{~g} / \mathrm{min}$ )

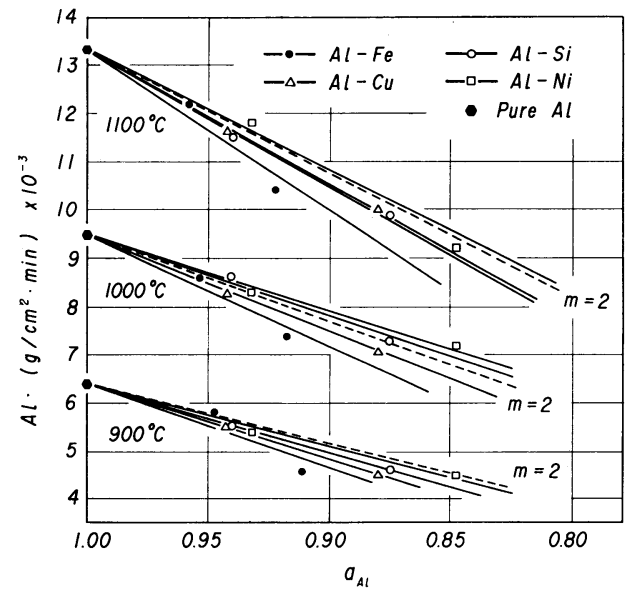

Fig.9 Relation between reaction velocity of $\mathrm{Al}$ in the alloys and aluminum activity (Flow rate of $\mathrm{AlCl}_{3}, 0.4 \mathrm{~g} / \mathrm{min}$ )

Jeannerod ${ }^{(13)}$ の值を引用したが，本実験の濃度範囲また実 験温度での測定值のないものは, 便宜的に測定値を外插し て, その濃度, 温度の活量とした。 また Niについては $1310^{\circ} \mathrm{C}$ の値をそのまま引用した。

これらの Fig.8, 9 は, 各温度において三塩化アルミニゥ ムの供給速度が $0.2,0.4 \mathrm{~g} / \mathrm{min}$ の場合について示したもの であるが，前記のモル濃度で表わした場合に比べて，活量 で表わすとそれぞれの合金系がいずれの温度でも明確な傾 向を示し, 次数 $m$ が 1 や 3 の場合よりも $m=2$ の線に適合 する結果となった. 以上のことから合金系の反応速度式 は,

$$
v=1.28 a_{\mathrm{Al}}^{2} P_{\mathrm{AlCl}_{3}}^{4 / 3} e^{-11800 / R T} \quad\left(\mathrm{Al} \mathrm{g} / \mathrm{cm}^{2} \cdot \mathrm{min}\right)
$$

なる式で近似的に表わされることがわかった.

一方, 三塩化アルミニウムの反応率について示したのが

Fig.10である.これは Al-Ni 系を例にとったものである が，反応温度が高いほどまた $\mathrm{Ni}$ 濃度が小さいほどその反

(12) 三谷, 永井 : 金属学会誌, 32 (1968), 752 .

(13) M.Jeannerod : The papers for the degree of master of science at the MIT(1966).

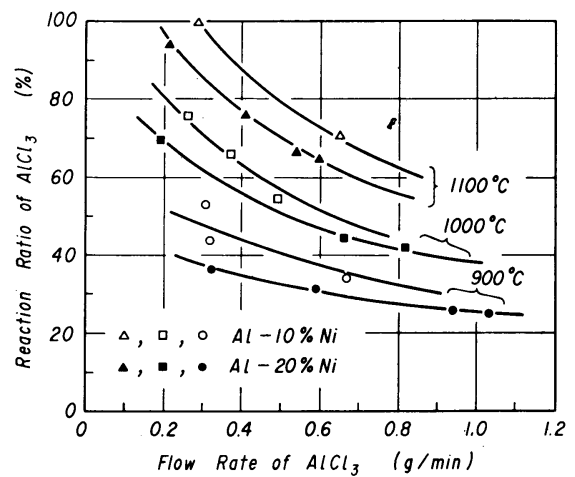

Fig.10 Relation between flow rate of $\mathrm{AlCl}_{3}$ and reaction ratio of $\mathrm{AlCl}_{3}$

応率は増加し, 三塩化アルミニウムの供給速度が増加する ほどその反応率は減少している。他の合金系についても Al-Ni 合金系と同様な傾向が認められた.

つぎに析出アルミニウムの純度について, 横軸に反応温 度, 縦軸に $\mathrm{Si}, \mathrm{Fe}$ の重量パーセントをとって示したのが

Fig.11である. 図にみるよ5に析出アルミニウムの中の $\mathrm{Fe}$ 濃度は大体 $0.1 \%$ 以下であり，また反応温度にはあま り依存しない。一方 $\mathrm{Si}$ の濃度は $0.2 \%$ 以下であり, Fe に 比べてやや多く，また高温になると増す傾向がある．また $\mathrm{Cu}$ については 0.001\% 以下であり, $\mathrm{Ni}$ は析出アルミニウ ム中にほとんど混入しないことが認められた.

つぎに析出アルミニウム中への不純物の混入について考 えてみる.この場合原料からは不純物が析出アルミニウム 中に機械的に混入しないものとし，すべて反応によるもの とする.これについては北川(14), 幸塚(9)らが述べているよ ろに, 合金中の $\mathrm{Fe}, \mathrm{Si}, \mathrm{Cu}, \mathrm{Ni}$ は三塩化アルミニウムとつ ぎのよ 5 に反応するものとする.
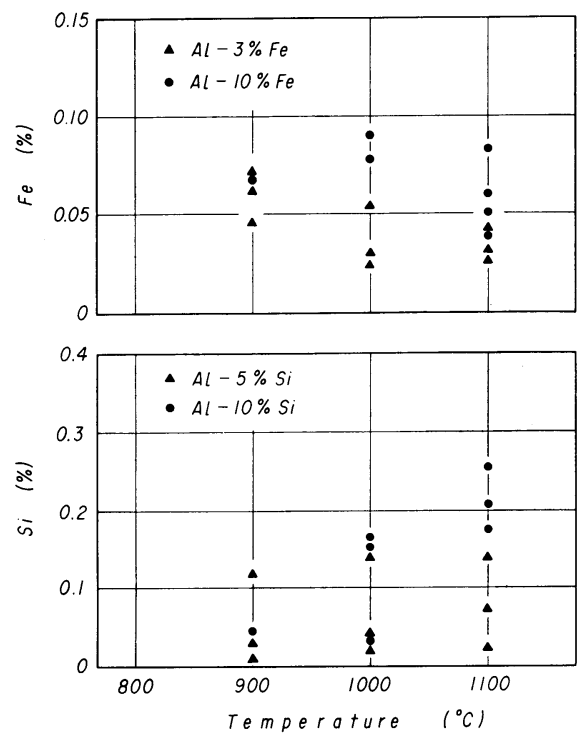

Fig.11 Relation between reaction temperature and $\mathrm{Si}, \mathrm{Fe}$ percentage in deposited $\mathrm{Al}$

(14) 北川：軽金属, $11(1964), 59$. 
$\mathrm{Fe}(\mathrm{s})+\mathrm{AlCl}_{3}(\mathrm{~g})=\mathrm{FeCl}_{2}(\mathrm{~g})+\mathrm{AlCl}(\mathrm{g})$

$\mathrm{Si}(\mathrm{s})+\mathrm{AlCl}_{3}(\mathrm{~g})=\mathrm{SiCl}_{2}(\mathrm{~g})+\mathrm{AlCl}(\mathrm{g})$

$\mathrm{Ni}(\mathrm{s})+\mathrm{AlCl}_{3}(\mathrm{~g})=\mathrm{NiCl}_{2}(\mathrm{~g})+\mathrm{AlCl}(\mathrm{g})$

$2 \mathrm{Cu}(\mathrm{s})+\mathrm{AlCl}_{3}(\mathrm{~g})=2 \mathrm{CuCl}(\mathrm{g})+\mathrm{AlCl}(\mathrm{g})$

これら以外に例えば $\mathrm{SiCl}_{4}$ 等 も考えられるが, Hirschwald(15) も述べているように，これ等は極めて微量 である.

不純物元素の混入の機構は明確でなく，一部では不純物 の塩化物ガスが析出アルミニウムによって還元されること も考えられるが, ここでは $\mathrm{FeCl}_{2}, \mathrm{SiCl}_{2}$ などが低温側のア ルミニウム析出帯で, 前述の逆反応により, サブクロライ ド反応で析出したアルミニウム中に不純物として混入する あのとする．この場合反応帯の平衡に拉けるサブクロライ ド反応の $\mathrm{AlCl}$ の分圧に比べて, 各金属の塩化物の分圧は 非常に小さいのでこのように考えても差支えないと思われ る. 以上のよ 5 に考えて, 熱力学的に計算して得た析出ア ルミニウム中の不純物の濃度を示したのが Fig.12であ る.な泾熱力学的数值は著者の求めた值 ${ }^{(4)}$, ならびに Kubaschewski ら ${ }^{(16)}$ ののを引用した。

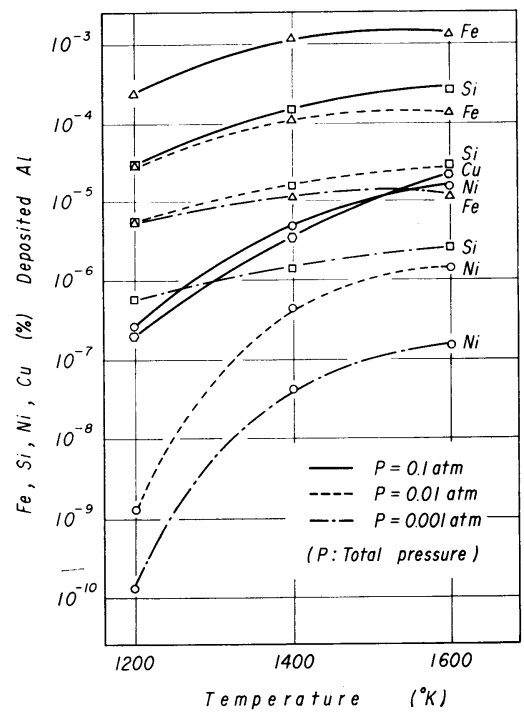

Fig.12 Calculated concentrations of elements in the deposited $\mathrm{Al}$ as a function of reaction temperature and total pressure

この罒は全圧がそれぞれ 0.1,0.01, $0.001 \mathrm{~atm}$ の場合に ついて, 反応温度と析出アルミニウムに混入する金属元素 の\%を表わしており，つぎのことがわかる.

まず $\mathrm{Ni}$ は不純物として最す混入乙難く，つぎに $\mathrm{Cu}, \mathrm{Si}$ ， Fe の順であり, 全圧が高くまた温度が高くなるほど不純 物がはいり易い. Si は Feよりも温度依存性がやや大きく，

(15) W.Hirschwald and O. Knake : Erzmetall, 3 (1958), 99.

(16) O.Kubaschewski, E.LL. Evans and C.B.Alcock : Metallurgical Thermochemistry, Pergamon Press, London, (1967) .
Ni は最も大きい. またもしこの平衡関係に近似した析出 物が得られたとすると，不純物はいずれる $10^{-3} \%$ オーダ 一以下の微量である.

ただし以上の諸結果は各元素の活量を 1 にとった場合で あり, 正しくは合金系中に含まれる各元素の活量の大小を 考虑せねばならず，また少量ながら $\mathrm{SiCl}_{4}$ などの生成も考 えられ, 不純物元素と三塩化アルミニウムの反応速度の相 違もあり得るが，不純物の混入の傾向を知る上ではかなり 役立つものと思われる.

この図に示した計算值と実験結果を比べてみると, $\mathrm{Ni} か ゙$ わずかしか混入しないこと, $\mathrm{Fe}, \mathrm{Si}$ が比較的混入し易いこ と, 温度依存性が Fe では少なく Si がやや大きいことなど は両者一致している.ただ熱力学的計算では不純物濃度は 10-3\%オーダーと非常に小さい值であるが，実際にはか なり大きい場合もあるようで，この点については Fe,Si な ど不純物元素と三塩化アルミニウムとの反応 ${ }^{(17)}$, 低温側 での混入機構, ならびに三谷, 永井(2)らが $\mathrm{FeO}, \mathrm{SiO}_{2}, \mathrm{Cu}_{2} \mathrm{O}$ などのような酸化物と $\mathrm{AlCl}$ が反応し易く，反応管材料か らの不純物混入が大きな関係をすつという興味ある研究を 行なっていることなど, さらに種々の要素を検討しなけれ ばならないであろう。

ここでは Si が Feよりも混入し易いことについて考えて みる. $\mathrm{Fe}, \mathrm{Si}$ の反応は前述したが, その平衡恒数は活量を 用いるとそれぞれ次式で示される.

$$
\begin{aligned}
& K_{P(\mathrm{Fe})}=P_{\mathrm{AlCl}} \cdot P_{\mathrm{FeCl}_{2}} / P_{\mathrm{AlCl}_{3}} \cdot a_{\mathrm{Fe} \text { (in alloy) }} \\
& K_{P(\mathrm{Si})}=P_{\mathrm{AlCl}} \cdot P_{\mathrm{SiCl}_{2}} / P_{\mathrm{AlCl}_{3}} \cdot a_{\mathrm{Si} \text { (in alloy) }}
\end{aligned}
$$

すなわち活量が小さくなればなるほど，平衡時のその元 素の塩化物の分圧は小さくなり，したがって不純物として 混入する量は減少する. このため $\mathrm{Al}-\mathrm{Fe}$ 系の Fe の活量を Pehlke ${ }^{(18)}$ ならびに三谷, 永井(12)の值, A1-Si 系の Si の活

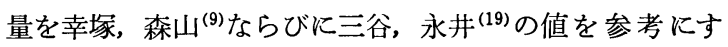
ると，本実験の合金組成範囲では $a_{\mathrm{Si}}>a_{\mathrm{Fe}}$ で， $a_{\mathrm{Si}}$ は $a_{\mathrm{Fe}}$ の 10 倍以上になり, 同一条件で $P_{\mathrm{SiCl}_{2}}$ は $P_{\mathrm{FeCl}_{2}}$ より大と なるため, 混入量も $\mathrm{Si}$ の方が多いるのと考えられる.

\section{IV. 総 括}

アルミニウムのサブクロライド製鍊に护ける $\mathrm{Si}, \mathrm{Fe}, \mathrm{Cu}$ ， $\mathrm{Ni}$ 添加の影響を検討し，つぎの結果を得た.

（1）いずれの合金系の場合でも，アルミニゥムの抽出速 度は $900^{\circ} \sim 1100^{\circ} \mathrm{C}$ の実験温度の範囲では, 高温ほどまた 三塩化アルミニウムの供給速度の多いほど増加した. しか し合金元素の濃度が高くなると減少する傾向を示した。

(2) 合金浴からのアルミニウムの抽出速度は, いずれの 合金系の場合でも実験濃度範团では, ささに著者が求めた 純アルミニウムのサブクロライド反応の速度式に合金系中

(17) M.F.Lee : J.Phys.Chem., 62(1958), 877.

(18) R.D.Pehlke : Trans. Met. Soc. AIME, 212 (1958), 486.

(19) 三谷, 永井 : 金属学会誌, 31 (1967), 1296. 
のアルミニウムの活量を代入し，

$v=1.28 a_{\mathrm{Al}}^{2} \cdot P_{\mathrm{AlCl} 3}^{4 / 3} \cdot e^{-11800 / R T} \quad\left(\mathrm{Al} \mathrm{g} / \mathrm{cm}^{2} \cdot \mathrm{min}\right)$ と表わすことができた

(3) 析出アルミニウム中の Si 濃度は $0.2 \%$ オーダー以 下，また Feは $0.05 \%$ オーダーで，一般に Si の方が Fe より多く混入する。また $\mathrm{Cu}$ 沄入嘗は $0.001 \%$ 以下であ ク, Ni は任とんど湿入しない。
（4）熱力学的計算を行ない，析出アルミニウム中への不 純物元素の混入量を求めた。この計算值と実験結果は傾向 の一致がみられた.

本研究は著者が金属材料技術研究所に勤務していた間に 行なったるので，御指導下さった同研究所柳橋哲夫博士。 ならびに黒沢利夫博士に厚く感謝申し上げをす。 